\title{
Coupled ESR and U-series dating of fossil teeth from Yiyuan hominin site, northern China
}

\author{
Fei Han ${ }^{1,2}$, Chengkai Sun ${ }^{2,3}$, Jean-Jacques Bahain ${ }^{4}$, Jianxin Zhao ${ }^{5}$, \\ Min Lin ${ }^{6}$, Song Xing ${ }^{2,7}$, Gongming Yin ${ }^{1}$
}

1. State Key Laboratory of Earthquake Dynamics, Institute of Geology, China

Earthquake Administration, Beijing 100029, China (hanfei@ies.ac.cn;

yingongming@sina.com)

2. State Key Laboratory of Palaeobiology and Stratigraphy, Nanjing Institute of Geology and Palaeontology, Chinese Academy of Sciences, Nanjing 210008, China

3. Shandong Museum, Jinan 250014, China (sunchengk@126.com)

4. Département de Préhistoire Muséum National d'Histoire Naturelle, UMR7194 du CNRS, 1, rue René Panhard 75013, Paris, France (bahain@mnhn.fr)

5. Radiogenic Isotope Facility, School of Earth Sciences, The University of Queensland, Brisbane, QLD 4072, Australia (j.zhao@uq.edu.au)

6. National Key Laboratory of Metrology and Calibration Technology, China Institute of Atomic Energy, Beijing 102413, China (minlin716@126.com)

7. Key Laboratory of Vertebrate Evolution and Human Origins, Institute of Vertebrate Paleontology and Paleoanthropology, Chinese Academy of Sciences, Beijing 100044, China (xingsong@ivpp.ac.cn)

*Corresponding authors: hanfei@ies.ac.cn; sunchengk@126.com

\section{Abstract}

Coupled ESR and U-series analyses of mammalian fossil teeth were carried out on two localities of Yiyuan hominin site (Locality 1 and 3) in northern China. The U-migration history of the fossil samples could be reconstructed by the combination of the two techniques, and overcome the limitation of stand-alone ESR and U-series age estimation. We obtained a combined ESR/U-series age (AU model) range from $\sim 420$ to $320 \mathrm{ka}$ from nine teeth recovered from the two localities, which pinpoints the 
deposition of hominin layer of Yiyuan site to M IS 11 to 9 . The age results in this study places Yiyuan site at the same time range of Zhoukoudian Locality 1 and Hexian Homo erectus sites. Comparing with other hominin sites, this study of Yiyuan Homo erectus site highlights the possibility of coexistence between Homo erectus and archaic $H$. sapiens in China.

Keywords: Yiyuan, fossil teeth, ESR/U-series dating, Homo erectus

\section{Introduction}

In 1981 and 1982, a fragment of human cranial vault bone, two fragments of supraorbital part of the frontal bone and seven human teeth were discovered from the two localities of Yiyuan site - Yiyuan Locality 1 (YYI) and Locality 3 (YYIII, $\sim 56 \mathrm{~m}$ south of YYI) during the excavation in a fissure deposit on Qizianshan limestone hill, Yiyuan County, Shandong Province, China (11809’E, 36²12’N) (Lu et al., 1989; Wu and Poirier, 1995) (Figure 1). The cranial fragment from YYI was recovered from small fragments of the parietals, frontal, and the occipital bones. Based on a morphological comparison, Lu et al. (1989) suggesting that both Yiyuan cranial fragments and teeth are similar to those of Zhoukoudian, and were attributed to Homo erectus. Additionally, a recent study of interproximal grooves on Yiyuan human teeth shows the evidences of tooth-picking behavior, probably as one of the earliest in eastern Asia (Sun et al., 2014).

YYI is a small limestone cave site filled with fluvial deposits, and YYIII nearby is a fissure site with the same kind of deposition as YYI. Five out of seven human teeth were unearthed from YYIII during the excavation in 1980s (Lu et al., 1989). However, due to road construction, the section of YYIII is completely covered by modern sediments, only YYI could be observed at the present time. Lu et al. (1989) made a detailed description of each layer of two localities, and pointed out that the stratigraphy of YYI and YYIII could be correlated. Five stratigraphic layers were hence recognized at the two localities (Figure 2). The human remains and abundant faunal remains were unearthed from layer 3. The association of Bovinae, Ursus arctos, Equus sanmeniensis, Sus lydekkeri and Megaloceros pachyosteus in the Yiyuan hominin layer was also recognized at Hexian and in layers 4-5 of Zhoukoudian locality 1, indicating a Middle 
Pleistocene age (Lu et al., 1989).

Despite the significance of the Yiyuan site, few chronological studies were carried out, and no numerical dating results were present since the discovery of the site. ESR/U-series method is a useful tool for dating fossil teeth from early human sites, as it could reconstruct the uranium migration history in the fossil teeth. Grün et al. (1988) proposed to couple ESR and U-series data to describe the U-uptake history in the different dental tissues (US-ESR model). The US-ESR model allows the calculation of an U-uptake parameter ( $p$-value) for each dental tissue, but it is restricted to $p \geq-1$, i.e. U-loss could not be modeled (Grün, 2009). In the case of U-leaching, an Accelerating Uptake (AU) model (Shao et al., 2012) was recently introduced which describes the U-uptake into dental tissue as an accelerating process. This model is able to reconstruct a process combining incorporation followed by leaching with two parameters, initial uptake rate, and acceleration of this uptake rate. It introduces also another uptake parameter, n-value, which corresponds to the ratio of acceleration of ${ }^{238} \mathrm{U}$ uptake rate and its initial uptake rate. Dating study of the Mauer site in Germany shows the AU model age obtained from the fossil teeth with U-leaching evidence is consistent with other independent age control (Shao et al., 2012).

In order to apply US-ESR or AU model for dating fossil samples, U-series analysis must be coupled with ESR measurement. The coupled ESR/U-series dating method was applied to date fossil teeth in a number of Early and Middle Pleistocene sites in Europe and Africa (e.g. Curnoe et al., 2001; Bahain et al., 2007; Falguères et al., 1999, 2010; Duval et al., 2012), as well as several hominid sites in China, including Hexian (Grün et al., 1998), Panxian Dadong (Jones et al., 2004), Dali (Yin et al., 2011), Chuifeng (Shao et al., 2014) and Longgupo (Han et al., in press). In the present study, nine fossil teeth from two localities (YYI and YYIII) of Yiyuan hominin site were analyzed by the ESR and U-series methods for establishing the chronology of the Yiyuan site. 


\section{Method and materials}

The fossil samples in this study were all collected during the early excavation of Yiyuan localities (YYI and YYIII) in 1980s. The fossil samples of YYI and YYIII were collected from the reddish-brown sandy clay layer 3 where the hominin fossils were unearthed (Figure 2, after Lu et al., 1989). Although the precise position of the samples were not recorded in the early excavation, as the hominin remains were recovered from the top of layer 3 , the fossil age should be contemporary or slightly older than the hominin fossils.

In this study, fossil teeth unearthed from hominin layers of YYI $(n=3)$ and YYIII $(n=6)$ were analyzed with the ESR and U-series methods (Table 1). All of the tooth samples except YYI-3 (Suidae) are herbivore molars. Samples YYIII-5a and YYIII-5b are two cervid molars derived from the same mandible fragment. The samples are well preserved in general and have both enamel and dentine tissues. These dental tissues initially were separated mechanically with dentist tools. The enamel was then ground and sieved into fine powder $(100-200 \mu \mathrm{m})$ and split into 10 or 15 aliquots for gamma irradiation from 32 to 12500 Gy in the National Key Laboratory of Metrology and Calibration Technology, China Institute of Atomic Energy. The uranium concentration and isotopic ratios of each dental tissue were analyzed by the U-series method with a Nu-Plasma MC-ICP-MS in the Radiogenic Isotope Facility, the University of Queensland, and combined with HpGe gamma spectrometer measurements in MNHN, Paris in order to evaluate possible radon loss from the dental tissues (Bahain et al., 1992).

The ESR intensity of enamel samples was measured by peak-to-peak amplitudes (T1-B2) of the ESR signal (Grün, 2000). Equivalent doses $\left(D_{E}\right)$ were determined by exponential plus linear (EPL) fitting function using Origin 8.5 software, with weighting by $1 / \mathrm{I}^{2}$. Two other fitting functions single saturation exponential (SSE) and double saturation exponential (DSE) were also tested and compared with EPL. The SSE function was traditionally used for $\mathrm{D}_{\mathrm{E}}$ determination in ESR dating. However, this function will cause systematic $\mathrm{D}_{\mathrm{E}}$ overestimation for fossil teeth samples (Duval et al., 2009). Although DSE function fits the dose points better than the SSE function, and 
could described the different dose responses of two $\mathrm{CO}_{2}^{-}$radicals in tooth enamel (Grün et al., 2008), we observed meaningless fitting parameters of DSE function in $D_{E}$ determination (the saturation level is below the natural aliquot measured intensity), and large uncertainty of $\mathrm{D}_{\mathrm{E}}$ up to $105 \%$. EPL was simpler than DSE, and gives compatible $\mathrm{D}_{\mathrm{E}}$ values with rational fitting parameters in this study. It also has similar adjusted R-square (Adj. $\mathrm{R}^{2}$ ) to the DSE function and relatively smaller uncertainty (3\% $\sim 15 \%$ ). Therefore, we choose EPL functions for $\mathrm{D}_{\mathrm{E}}$ determination of Yiyuan fossil samples.

In situ gamma dose rate of YYI was measured by Ortec DigiDART portable gamma spectrometer with a NaI detector using the threshold method (Mercier and Falguères, 2007). Although the stratigraphic section of YYIII could not be observed, the unearthed position of the tooth samples were recorded from the reddish-brown sandy clay fossil layer 3 as YYI which contains the hominin remains. In order to better constrain the external dose rate, we measured three different places in the fossil layer of YYI, and took the mean value of three points $(3.12 \pm 0.58 \mathrm{~Gy} / \mathrm{ka})$ for external gamma dose rate of both YYI and YYIII. The sediments were collected and analyzed at MNHN by laboratory HpGe gamma spectrometer for external beta dose rate determination, and a sediment water content of $15 \pm 5 \%$ was assumed for fossil age calculation (Table 2).

\section{Results and discussion}

The uranium contents and $\mathrm{U}$-series isotopic ratios $\left({ }^{234} \mathrm{U} /{ }^{238} \mathrm{U}\right.$ and $\left.{ }^{230} \mathrm{Th} /{ }^{234} \mathrm{U}\right)$ of Yiyuan fossil teeth samples were shown in Table 1. The U contents range between 0.97 and $6.06 \mathrm{ppm}$ in enamel samples, and from 16.81 to $38.47 \mathrm{ppm}$ in dentine tissue. The measured ${ }^{234} \mathrm{U} /{ }^{238} \mathrm{U}$ and ${ }^{230} \mathrm{Th} /{ }^{234} \mathrm{U}$ ratios of both dental tissues vary from 1.519 to 2.057 and 1.102 to 1.797 , respectively, and the beyond equilibrium ratios of ${ }^{230} \mathrm{Th} /{ }^{234} \mathrm{U}$ $(>1.04)$ indicate uranium leaching. The US-ESR model could not be applied for age calculation, and the AU model was therefore systematically used in this study.

The $\mathrm{n}$ values calculated for the Yiyuan samples are all negative (Table 2), as a result of the uranium-series open system which has evolved beyond equilibrium state. The dose rate components calculated with the AU model and their contributions to the total 
dose rate are shown in Table 2. For Yiyuan samples, the gamma and beta dose rates from the sediments are more than half of the total dose rates, which range from $51 \%$ to $82 \%$. The percentages of internal dose rate from enamel are no more than $20 \%$ of the total dose rates, except for YYI-02 (47\%).

The AU model ages of two samples of three from YYI show good agreement, and give an weighted mean age of $344 \pm 19 \mathrm{ka}$. The six teeth from YYIII are consistent in the error range, and their weighted mean AU model age is $400 \pm 19 \mathrm{ka}$. The main uncertainty of age calculation of YYIII comes from the external dose rate which cannot be reconstructed directly at present due to the construction, and we used the measured values of coeval layer of YYI (layer 3) instead. Although the mean fossil ages of YYIII are $\sim 60$ ky older than YYI, the result of the two sites are in agreement with the faunal evidence which indicating a middle period of Middle Pleistocene age (300-600ka, Dong, in press), between MIS 11 and 9 (Figure 3).

Comparing with the human remains from other Homo erectus sites in China, Lu et al. (1989) suggested that the Yiyuan cranial fragments are morphologically closer to Zhoukoudian than to Hexian, and the degree of postorbital constriction is intermediate between the Zhoukoudian and Hexian specimens. In this study, the dated two Yiyuan localities were compared with nearby Homo erectus sites and some other recently dated archaic Homo sapiens (Middle Pleistocene hominins that morphologically and behaviorally fall between H. erectus and modern H. sapiens (Stringer, 2002; Bae, 2013) sites in China (Figure 4). According to the chronological study by multiple dating techniques, the hominin presence at Zhoukoudian Locality 1 is constrained to a range of 0.40 0.78 Ma (Grün et al., 1997; Shen et al., 2001, 2009). The combined ESR/U-series ages of both YYI and YYIII obtained in this study fall within the total time range (layers 1-10) of Zhoukoudian Locality 1 (ZKD1), which agrees with the fauna evidences which show similarity of YYI, YYIII and layers 4-5 of ZKD1 (400-600 ka, Shen et al., 2009); The age of Yiyuan sites were also consistent with Hexian Homo erectus site nearby $(412 \pm 25 \mathrm{ka})$ (Figure 4). Although the Yiyuan cranial fragments are morphologically closer to ZKD1 specimens than Hexian (Lu et al., 1989), these variations are attributed to regional differentiation of Homo erectus evolution in China, 
as they are all in the same time range (Xing et al., 2014).

Compared with some archaic Homo sapiens sites in China, such as Chaoxian (310 360 ka) (Shen et al., 2010), Dali (258 327 ka) (Yin et al., 2011; Wu and Athreya, 2013; Sun et al., accepted) and perhaps Maba (no younger than $278 \pm 4 \mathrm{ka}$ ) (Shen et al., 2014; Xiao et al., 2014), which were dated with updated techniques or protocols, a potential overlap could be observed (Figure 4). This suggests the possibility of an earlier interface between $H$. erectus and archaic $H$. sapiens in China, mentioned repeatedly based on chronological studies on several Chinese sites (Chen and Yuan, 1991; Shen et al., 2010, 2014). High-resolution U-series dating of speleothem calcites and combined ESR/U-series dating of fossil tooth directly coupled with other sediment and stone artifacts dating methods, such as OSL and ${ }^{26} \mathrm{Al} /{ }^{10} \mathrm{Be}$ burial dating, will provide more evidence to resolve the question of the coexistence of these two Homo species. This dating study also places the Yiyuan hominin as one of the earliest chronological evidence of tooth-picking by hominins in China and East Asia, earlier than the Huanglong Cave evidence (81 101ka) (Liu et al., 2010; Shen et al., 2013; Sun et al., 2014).

\section{Conclusion}

Coupled ESR and U-series dating was applied on nine teeth from two localities of Yiyuan Homo erectus site (YYI and YYIII) in China. Uranium leaching of all the samples was indicated by U-series analysis and the AU model has been used for fossil age calculation. Nine fossil teeth samples from YYI and YYIII give an age range from $\sim 320$ to $420 \mathrm{ka}$. This places the deposition of hominin layers of Yiyuan site to the time

between MIS 11 and 9. The dating places Yiyuan site in the same time range with Zhoukoudian Locality 1 and Hexian Homo erectus sites. Compared with other recently dated hominin sites, this dating study of Yiyuan Homo erectus site highlights the possibility of coexisetence of Homo erectus with archaic $H$. sapiens in China.

\section{Acknowledgements}

This study was supported by National Science Foundation of China (Grant No. 
41302139), State Key Laboratory of Earthquake Dynamics, Institute of Geology, China

Earthquake Administration (Project No. LED2014A05) and State Key Laboratory of Palaeobiology and Stratigraphy, Nanjing Institute of Geology and Palaeontology, CAS (Project No. 133112). We thank Yang Zhonghua, Zheng Deping and Liu Hongliang from Yiyuan Museum for helping in situ dose rate measurement. We also thank Dr. Shen Guanjun, Shao Qingfeng and Tu Hua for helpful discussion.

\section{References}

Adamiec, G. and Aitken, M. J., 1998. Dose-rate conversion factors: update. Ancient TL $16,37-50$.

Bae, C. J., 2013. Archaic Homo sapiens. Nature Education Knowledge 4(8):4.

Bahain, J.-J., Falguères, C., Laurent, M., Voinchet, P., Dolo, J.-M., Antoine, P., and Tuffreau, A., 2007. ESR chronology of the Somme River Terrace system and first human settlements in Northern France. Quaternary Geochronology 2, 356-362.

Bahain, J.-J., Yokoyama, Y., Falguères, C., and Sarcia, M. N., 1992. ESR dating of tooth enamel: A comparison with K-Ar dating. Quaternary Science Reviews 11, $245-250$.

Chen, T. and Yuan, S., 1991. Uranium-series dating of bones and teeth from Chinese Palaeolithic sites. Archaeometry 30, 59-76.

Chen, T. and Zhang, Y. Y., 1991. Palaeolithic chronology and possible coexistence of Homo erectus and Homo sapiens in China. World Archaeology 23, 147-154.

Curnoe, D., Grün, R., Taylor, L., Thackeray, F., 2001. Direct ESR dating of a Pliocene hominin from Swartkrans. Journal of Human Evolution 40, 379-391.

Dong, W., Biochronological framework of Homo erectus horizons in China. Quaternary International, in press, this volume.

Duval, M., Falguères, C., and Bahain, J.-J., 2012. Age of the oldest hominin settlements in Spain: contribution of the combined U-series/ESR dating method applied to fossil teeth. Quaternary Geochronology 10, 412-417.

Duval, M., Grün, R., Falguères, C., Bahain, J.-J., and Dolo, J.-M., 2009. ESR dating of 
Lower Pleistocene fossil teeth: Limits of the single saturating exponential (SSE) function for the equivalent dose determination. Radiation Measurements 44, $477-482$.

Falguères, C., Bahain, J.-J., Duval, M., Shao, Q., Han, F., Lebon, M., Mercier, N., Perez-Gonzalez, A., Dolo, J.-M., and Garcia, T., 2010. A 300-600ka ESR/U-series chronology of Acheulian sites in Western Europe. Quaternary International 223, 293-298.

Falguères, C., Bahain, J.-J., Yokoyama, Y., Arsuaga, J. L., de Castro, J. M. B., Carbonell, E., Bischoff, J. L., and Dolo, J.-M., 1999. Earliest humans in Europe: the age of TD6 Gran Dolina, Atapuerca, Spain. Journal of Human Evolution 37, 343-352.

Grün, R., 2000. Methods of dose determination using ESR spectra of tooth enamel. Radiation Measurements 32, 767-772.

Grün, R., 2009. The relevance of parametric U-uptake models in ESR age calculations. Radiation Measurements 44, 472-476.

Grün, R., Huang, P.-H., Huang, W., McDermott, F., Thorne, A., Stringer, C. B., and Yan, G., 1998. ESR and U-series analyses of teeth from the palaeoanthropological site of Hexian, Anhui Province, China. Journal of Human Evolution 34, 555-564.

Grün, R., Huang, P.-H., Wu, X., Stringer, C. B., Thorne, A. G., and McCulloch, M., 1997. ESR analysis of teeth from the palaeoanthropological site of Zhoukoudian, China. Journal of Human Evolution 32, 83-91.

Grün, R., Joannes-Boyau, R., and Stringer, C., 2008. Two types of $\mathrm{CO}_{2}{ }^{-}$radicals threaten the fundamentals of ESR dating of tooth enamel. Quaternary Geochronology 3, 150-172.

Grün, R. and Katzenberger-Apel, O., 1994. An alpha irradiator for ESR dating. Ancient TL 12.

Grün, R., Schwarcz, H. P., and Chadam, J., 1988. ESR dating of tooth enamel: coupled correction for U-uptake and U-series disequilibrium. International Journal of Radiation Applications and Instrumentation. Part D. Nuclear Tracks 
and Radiation Measurements 14, 237-241.

Han, F., Bahain, J.-J., Deng, C.L., Boëda, É., Hou, Y.M., Wei, G.B., Huang, W.B., Garcia, T., Shao, Q.F., He, C.D., Falguères C., Voinchet, P., Yin, G.M., The earliest evidence of hominid settlement in China - combined electron spin resonance and uranium series (ESR/U-series) dating of mammalian fossil teeth from Longgupo cave. In press. (http://dx.doi.org/10.1016/j.quaint.2015.02.025)

Ikeya, M., 1982. A model of linear uranium accumulation for ESR age of Heidelberg (Mauer) and Tautavel bones. Japanese Journal of Applied Physics 21, L690.

Jones, H., Rink, W., Schepartz, L., Miller-Antonio, S., Weiwen, H., Yamei, H., and Wei, W., 2004. Coupled electron spin resonance (ESR)/uranium-series dating of mammalian tooth enamel at Panxian Dadong, Guizhou Province, China. Journal of Archaeological Science 31, 965-977.

Lisiecki, L. E. and Raymo, M. E., 2005. A Pliocene $\square$ Pleistocene stack of 57 globally distributed benthic $\delta 180$ records. Paleoceanography 20, PA1003, doi:10.1029/2004PA001071

Liu, W., Wu, X., Pei, S., Wu, X., and Norton, C. J., 2010. Huanglong Cave: a late Pleistocene human fossil site in Hubei Province, China. Quaternary International 211, 29-41.

Liu, X., Shen, G., Tu, H., Lu, C., and Granger, D. E., 2014. Initial ${ }^{26} \mathrm{Al} /{ }^{10} \mathrm{Be}$ burial dating of the hominin site Bailong Cave in Hubei Province, central China. Quaternary International. In press

Lu, Z., Huang, Y., Li, P., and Meng, Z., 1989. Yiyuan fossil man. Acta Anthropologica Sinica 8, 301-313.

Marsh, R., Prestwich, W., Rink, W. J., and Brennan, B., 2002. Monte Carlo determinations of the beta dose rate to tooth enamel. Radiation Measurements $35,609-616$.

Mercier, N. and Falguères, C., 2007. Field gamma dose-rate measurement with a NaI (Tl) detector: re-evaluation of the "threshold" technique. Ancient TL 25, 1-4.

Rae, A. M. and Ivanovich, M., 1986. Successful application of uranium series dating of fossil bone. Applied Geochemistry 1, 419-426. 
Shao, Q., Bahain, J.-J., Falguères, C., Dolo, J.-M., and Garcia, T., 2012. A new U-uptake model for combined ESR/U-series dating of tooth enamel. Quaternary Geochronology 10, 406-411.

Shao, Q., Wang, W., Deng, C., Voinchet, P., Lin, M., Zazzo, A., Douville, E., Dolo, J.-M., Falguères, C., and Bahain, J.-J., 2014. ESR, U-series and paleomagnetic dating of Gigantopithecus fauna from Chuifeng Cave, Guangxi, southern China. Quaternary Research 82, 270-280.

Shen, G., Fang, Y., Bischoff, J. L., Feng, Y.X., and Zhao, J.X., 2010. Mass spectrometric U-series dating of the Chaoxian hominin site at Yinshan, eastern China. Quaternary International 211, 24-28.

Shen, G., Gao, X., Gao, B., and Granger, D. E., 2009. Age of Zhoukoudian Homo erectus determined with ${ }^{26} \mathrm{Al} /{ }^{10} \mathrm{Be}$ burial dating. Nature 458, 198-200.

Shen, G., Ku, T.-L., Cheng, H., Edwards, R. L., Yuan, Z., and Wang, Q., 2001. High-precision U-series dating of Locality 1 at Zhoukoudian, China. Journal of Human Evolution 41, 679-688.

Shen, G., Tu, H., Xiao, D., Qiu, L., Feng, Y.X., and Zhao, J.X., 2014. Age of Maba hominin site in southern China: Evidence from U-series dating of Southern Branch Cave. Quaternary Geochronology 23, 56-62.

Shen, G., Wu, X., Wang, Q., Tu, H., Feng, Y.X., and Zhao, J.X., 2013. Mass spectrometric U-series dating of Huanglong Cave in Hubei Province, central China: Evidence for early presence of modern humans in eastern Asia. Journal of Human Evolution 65, 162-167.

Stringer, C. (2002). Modern human origins: progress and prospects. Philosophical Transactions of the Royal Society B: Biological Sciences 357(1420), 563-579.

Sun, C., Xing, S., Martín-Francés, L., Bae, C., Liu, L., Wei, G., and Liu, W., 2014. Interproximal grooves on the Middle Pleistocene hominin teeth from Yiyuan, Shandong Province: New evidence for tooth-picking behavior from eastern China. Quaternary International 354, 162-168.

Sun, X. F., Yi, S. W., Lu, H. Y., and Zhang, W. C., TT-OSL and post-IR IRSL dating of the Dali Man site in central China. Quaternary International. Accepted. 
Tu, H., Shen, G., Li, H., Xie, F., and Granger, D. E., 2015. ${ }^{26} \mathrm{Al} /{ }^{10} \mathrm{Be}$ burial dating of Xujiayao-Houjiayao site in Nihewan Basin, northern China. PLoS ONE 10(2): e0118315. doi:10.1371/journal.pone.0118315

Wu, X., Poirier, F. E., 1995. Human evolution in China: a metric description of the fossils and a review of the sites. Oxford University Press. New York.

Wu, X., and Athreya, S., 2013. A description of the geological context, discrete traits, and linear morphometrics of the Middle Pleistocene hominin from Dali, Shaanxi Province, China. American Journal of Physical Anthropology 150, 141-157.

Xiao, D., Bae, C. J., Shen, G., Delson, E., Jin, J. J., Webb, N. M., and Qiu, L., 2014. Metric and geometric morphometric analysis of new hominin fossils from Maba (Guangdong, China). Journal of Human Evolution 74, 1-20.

Xing, S., Martinón-Torres, M., Bermúdez de Castro, J.M., Zhang, Y., Fan, X., Zheng,

L., Huang, W., Liu, W., 2014. Middle Pleistocene hominin teeth from Longtan Cave, Hexian, China. PLoS ONE 9, e114265.

Xing, S., Martinón-Torres, M., Bermúdez de Castro, J. M., Wu, X., and Liu, W., 2015. Hominin teeth from the early Late Pleistocene site of Xujiayao, Northern China. American Journal of Physical Anthropology 156, 224-240.

Yin, G., Bahain, J.-J., Shen, G., Tissoux, H., Falguères, C., Dolo, J.-M., Han, F., and Shao, Q., 2011. ESR/U-series study of teeth recovered from the palaeoanthropological stratum of the Dali Man site (Shaanxi Province, China). Quaternary Geochronology 6, 98-105.

Zhao, J.X., Hu, K., Collerson, K. D., and Xu, H.K., 2001. Thermal ionization mass spectrometry U-series dating of a hominid site near Nanjing, China. Geology 29, 27-30.

Zhang, J.F., Huang, W.-W., Hu, Y., Yang, S.-X., and Zhou, L.P., Optical dating of flowstone and silty carbonate-rich sediments from Panxian Dadong Cave, Guizhou, southwestern China. Quaternary Geochronology. In press

Figure captions: 
Figure 1 Location of Yiyuan site and other hominin sites mentioned in this study (Bird's-eye view of Yiyuan Locality 1 and Locality 3 came from Google Earth Pro) Figure 2 Stratigraphy of Yiyuan Locality 1 (YYI) and Locality 3 (YYIII) after Lu et al. (1989).

Figure 3 Coupled ESR/U-series ages of Yiyuan site obtained in this study and the corresponding marine isotopic stage. (light blue shadow indicates the time range of weighted mean age with error of fossil teeth samples from Yiyuan Locality 1 (YYI) and Locality 3 (YYIII))

Figure 4 The combined ESR/U-series ages of Yiyuan site obtained in this study compared with other recently dated hominin sites (H. erectus and archaic H. sapiens) in China. (YYI, YYIII - Yiyuan Locality 1 and 3 (this study), ZKD1 - Zhoukoudian Locality 1 layers 1-10 (Grün et al., 1997; Shen et al., 2001, 2009), HX - Hexian (Grün et al., 1998), TS - Tangshan (Zhao et al., 2001), BLD - Bailongdong (Liu et al., in press), CX - Chaoxian (Shen et al., 2010), DL - Dali (Yin et al., 2011; Sun et al., accepted), MB - Maba (Shen et al., 2014), XJY - Xujiayao (Tu et al., 2015), PXDD Panxian Dadong (Jones et al., 2004; Zhang et al., in press))

\section{Table captions:}

Table 1 Basic information and U-series measured data of Yiyuan fossil teeth

Table 2 Dose rate components and ESR/U-series ages (AU model) of Yiyuan teeth samples 
Figure 1

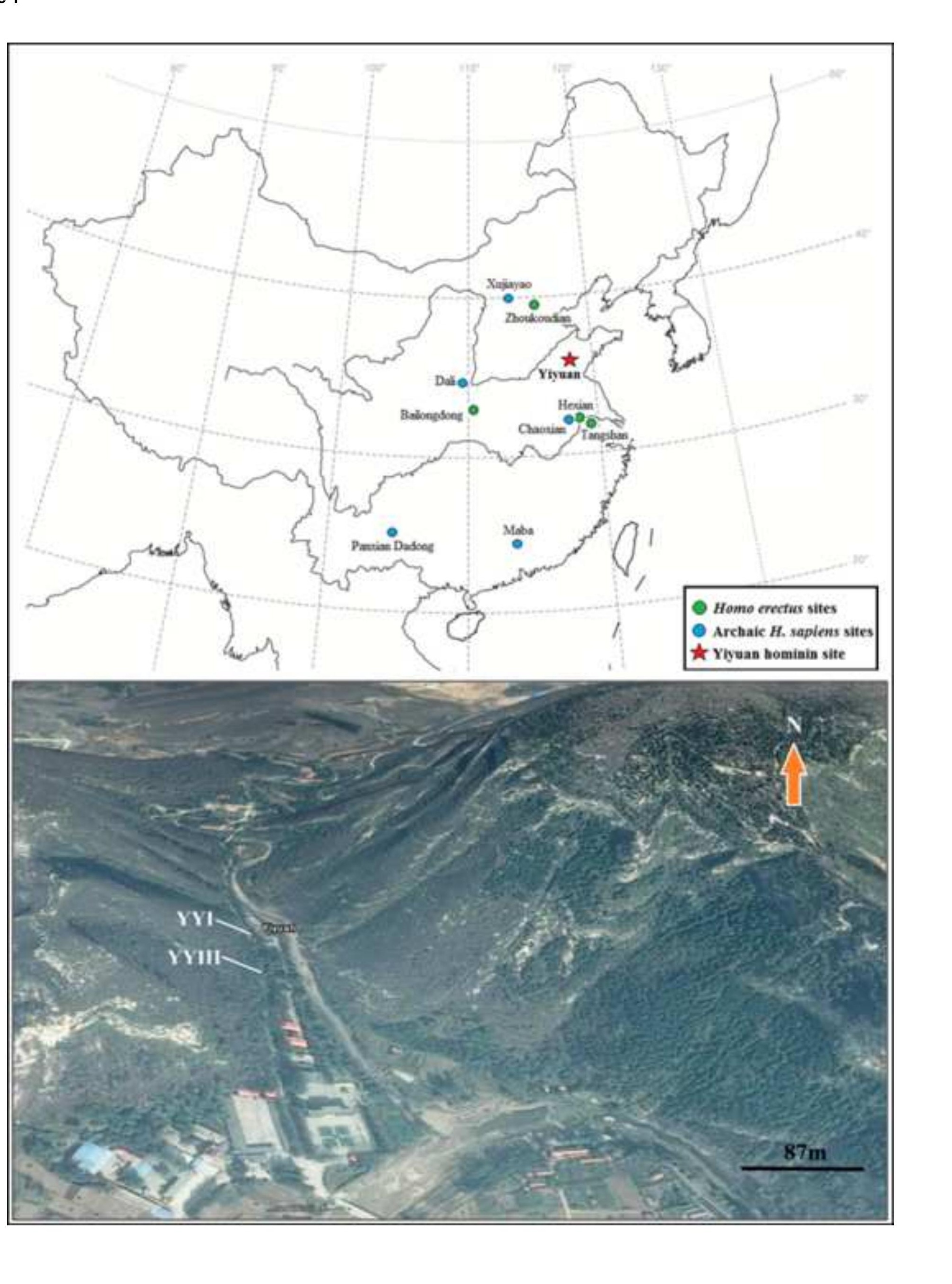

\section{Fure 1}




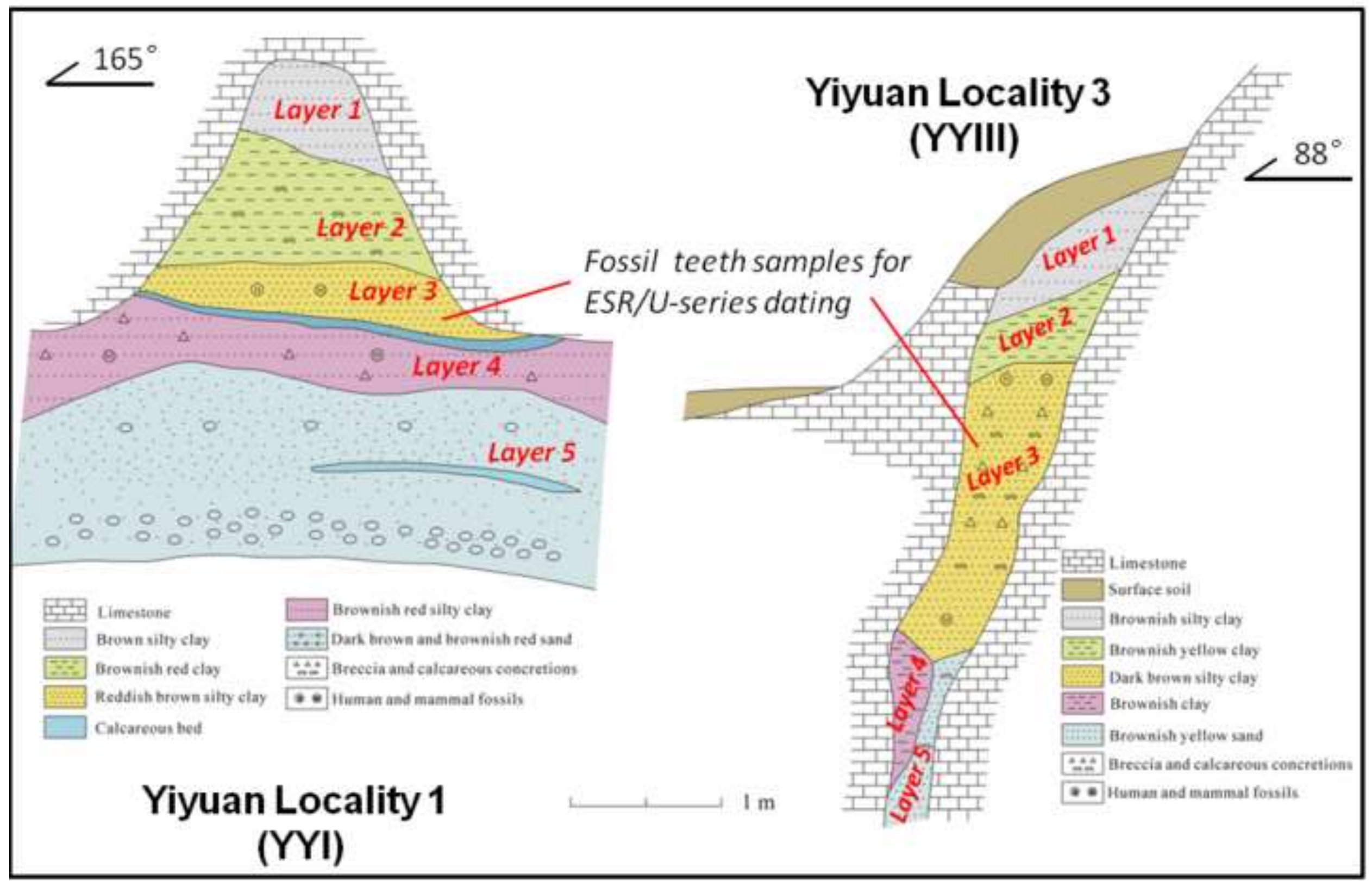




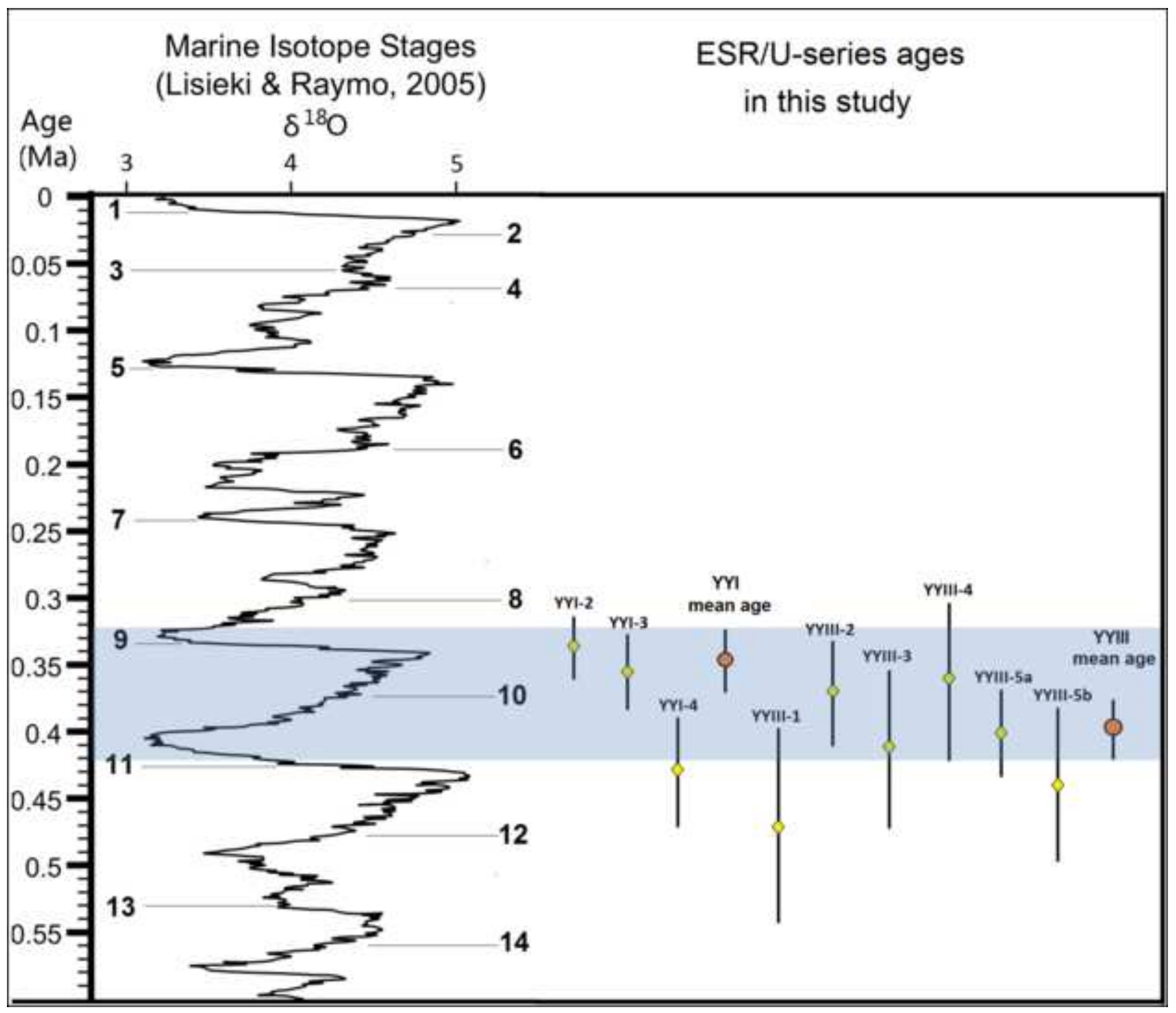




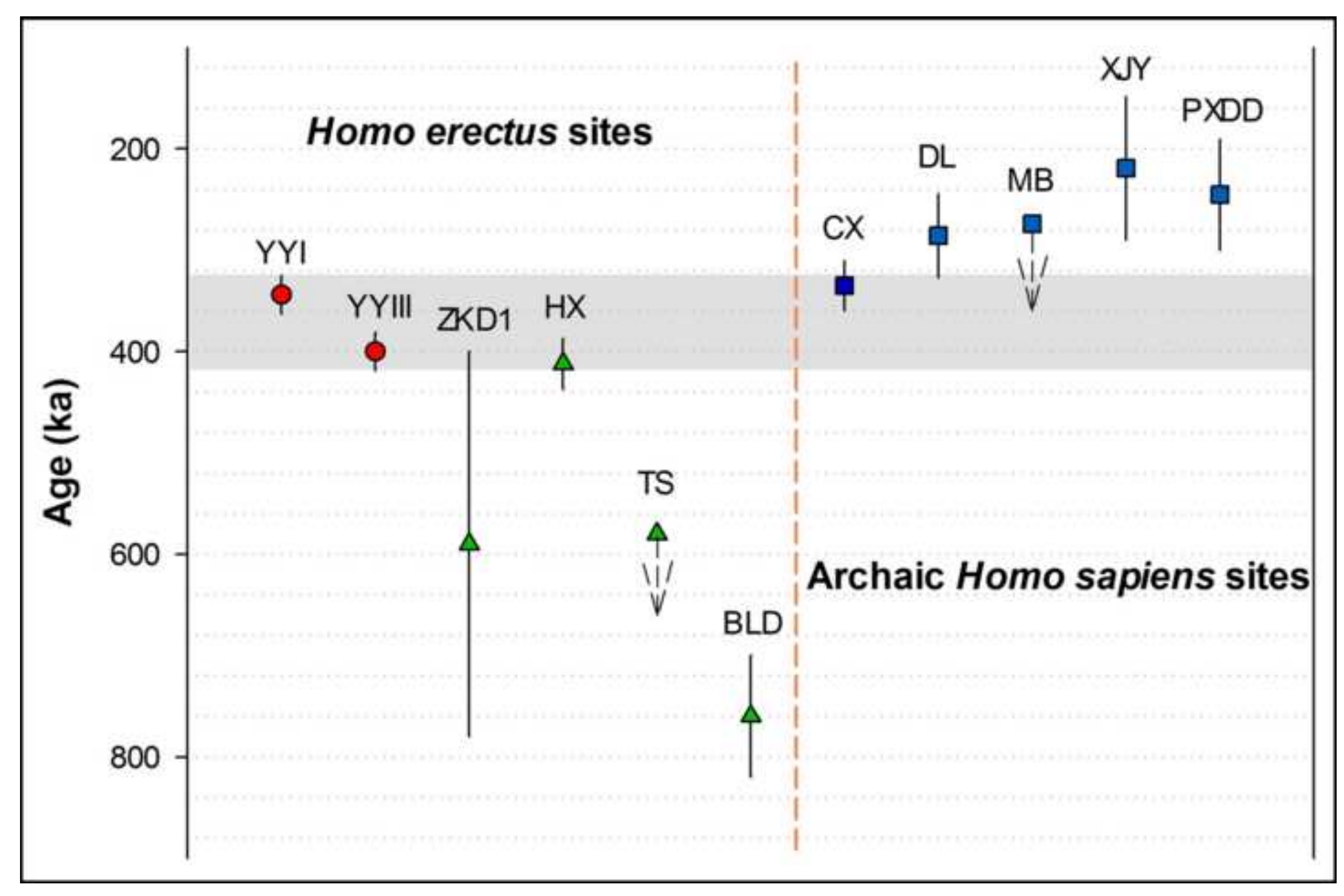


Table 1 Basic information and U-series measured data of Yiyuan fossil teeth

\begin{tabular}{|c|c|c|c|c|c|c|c|c|c|c|c|c|c|}
\hline \multirow{3}{*}{$\begin{array}{c}\text { Sample } \\
\text { No. } \\
\text { YYI-2 }\end{array}$} & \multirow{3}{*}{$\begin{array}{c}\text { Species } \\
\text { Bovid }\end{array}$} & \multirow{3}{*}{$\begin{array}{l}\text { Tissue } \\
\text { enamel } \\
\text { dentine }\end{array}$} & \multirow{2}{*}{ 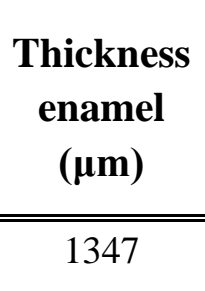 } & \multirow{2}{*}{$\begin{array}{c}\begin{array}{c}\text { Removed } \\
\text { enamel } \\
\left(\mathbf{S 1} / \mathbf{S} 2^{*}\right) \\
(\boldsymbol{\mu m})\end{array} \\
86 / 70\end{array}$} & \multicolumn{3}{|c|}{$\begin{array}{c}\text { U-content } \\
(\mathbf{p p m})\end{array}$} & \multicolumn{3}{|c|}{${ }^{234} \mathbf{U} /{ }^{238} \mathbf{U}$} & \multicolumn{2}{|c|}{${ }^{230} \mathrm{Th} /{ }^{234} \mathrm{U}$} & \multirow{2}{*}{$\begin{array}{c}{ }^{222} \mathbf{R n} /{ }^{230} \mathbf{T h} * \\
0.627\end{array}$} \\
\hline & & & & & 6.064 & \pm & 0.004 & 1.8548 & \pm & 0.0019 & 1.2421 & \pm 0.0030 & \\
\hline & & & & & 16.808 & \pm & 0.014 & 1.8904 & \pm & 0.0018 & 1.5674 & \pm 0.0045 & 0.332 \\
\hline \multirow{2}{*}{ YYI-3 } & \multirow{2}{*}{ Sus } & enamel & 2052 & $110 / 97$ & 2.398 & \pm & 0.005 & 1.5192 & \pm & 0.0036 & 1.1430 & $\pm \quad 0.0088$ & 0.560 \\
\hline & & dentine & & & 27.352 & \pm & 0.336 & 1.8686 & \pm & 0.0060 & 1.6945 & $\pm \quad 0.0412$ & 0.233 \\
\hline \multirow{2}{*}{ YYI-4 } & \multirow{2}{*}{ Cervid } & enamel & 1003 & $45 / 45$ & 1.260 & \pm & 0.001 & 1.6320 & \pm & 0.0022 & 1.2071 & \pm 0.0031 & 0.934 \\
\hline & & dentine & & & 18.489 & \pm & 0.011 & 1.8983 & \pm & 0.0015 & 1.5941 & \pm 0.0035 & 0.391 \\
\hline \multirow{2}{*}{ YYIII-1 } & \multirow{2}{*}{ Equid } & enamel & 1239 & $66 / 47$ & 1.593 & \pm & 0.001 & 1.6573 & \pm & 0.0018 & 1.1199 & \pm 0.0036 & 0.707 \\
\hline & & dentine & & & 34.231 & \pm & 0.017 & 1.8022 & \pm & 0.0010 & 1.3134 & $\pm \quad 0.0028$ & 0.318 \\
\hline \multirow{2}{*}{ YYIII-2 } & \multirow{2}{*}{ Cervid } & enamel & 1102 & $59 / 57$ & 0.975 & \pm & 0.001 & 1.7170 & \pm & 0.0025 & 1.1733 & \pm 0.0028 & 0.707 \\
\hline & & dentine & & & 19.868 & \pm & 0.016 & 2.0574 & \pm & 0.0026 & 1.7967 & \pm 0.0040 & 0.318 \\
\hline \multirow{2}{*}{ YYIII-3 } & \multirow{2}{*}{ Cervid } & enamel & 1169 & $87 / 52$ & 1.493 & \pm & 0.001 & 1.7484 & \pm & 0.0016 & 1.1019 & \pm 0.0027 & 0.707 \\
\hline & & dentine & & & 16.896 & \pm & 0.009 & 1.9801 & \pm & 0.0018 & 1.5674 & $\pm \quad 0.0042$ & 0.318 \\
\hline \multirow{2}{*}{ YYIII-4 } & \multirow{2}{*}{ Cervid } & enamel & 920 & $160 / 82$ & 2.032 & \pm & 0.001 & 1.6839 & \pm & 0.0016 & 1.2001 & \pm 0.0028 & 0.707 \\
\hline & & dentine & & & 30.075 & \pm & 0.015 & 1.8485 & \pm & 0.0015 & 1.4425 & \pm 0.0032 & 0.318 \\
\hline \multirow{2}{*}{ YYIII-5a } & \multirow{2}{*}{ Cervid } & enamel & 951 & $85 / 90$ & 1.867 & \pm & 0.001 & 1.6259 & \pm & 0.0020 & 1.2118 & $\pm \quad 0.0025$ & 0.707 \\
\hline & & dentine & & & 38.471 & \pm & 0.021 & 1.8666 & \pm & 0.0020 & 1.4890 & \pm 0.0049 & 0.318 \\
\hline \multirow{2}{*}{ YYIII-5b } & \multirow{2}{*}{ Cervid } & enamel & 988 & $55 / 52$ & 2.308 & \pm & 0.001 & 1.5351 & \pm & 0.0013 & 1.1494 & 0.0027 & 0.707 \\
\hline & & dentine & & & 38.365 & \pm & 0.025 & 1.8660 & \pm & 0.0022 & 1.4719 & \pm 0.0046 & 0.318 \\
\hline
\end{tabular}

*Note: S1, S2 represent the dentine and sediment sides attached to enamel respectively; Rn loss was calculated with combined U-series data measured by MC-ICP-MS and gamma spectrometers, and the mean values of Rn loss of both enamel and dentine tissues of YYI samples were applied on YYIII. 
Table 2 Dose rate components and ESR/U-series ages (AU model) of Yiyuan teeth samples

\begin{tabular}{|c|c|c|c|c|c|c|c|c|c|}
\hline $\begin{array}{c}\text { Sample } \\
\text { No. }\end{array}$ & Species & Tissue & $D_{E}(G y)^{*}$ & $\begin{array}{c}\text { Internal } \\
\text { dose }(\alpha+\beta) \\
\text { enamel } \\
(\mu \mathrm{Gy} / \mathbf{a}) \\
\end{array}$ & $\begin{array}{c}\beta \text { dentine } \\
(\mu \mathrm{Gy} / \mathbf{a})\end{array}$ & $\begin{array}{c}\beta \\
\text { sediment } \\
(\mu \mathrm{Gy} / \mathbf{a})\end{array}$ & $\begin{array}{c}\text { Total } \\
\text { dose rate } \\
(\mu \mathrm{Gy} / \mathbf{a})^{* *}\end{array}$ & $\begin{array}{c}\text { n-values } \\
\text { (w.u.) }\end{array}$ & $\begin{array}{c}\text { AU-ESR } \\
\text { age } \\
(\mathbf{k a})^{* * * *}\end{array}$ \\
\hline YYI-2 & Bovid & $\begin{array}{l}\text { enamel } \\
\text { dentine }\end{array}$ & $2205.37 \pm 104.55$ & $3049 \pm 480$ & $170 \pm 27$ & $186 \pm 10$ & $6525 \pm 573$ & $\begin{array}{l}-0.0042 \pm 0.00038 \\
-0.0045 \pm 0.00039\end{array}$ & $338 \pm 25$ \\
\hline YYI-3 & Sus & $\begin{array}{l}\text { enamel } \\
\text { dentine }\end{array}$ & $1507.81 \pm 52.73$ & $872 \pm 235$ & $164 \pm 44$ & $115 \pm 10$ & $4271 \pm 393$ & $\begin{array}{l}-0.0039 \pm 0.00041 \\
-0.0044 \pm 0.00043\end{array}$ & $353 \pm 30$ \\
\hline YYI-4 & Cervid & $\begin{array}{l}\text { enamel } \\
\text { dentine }\end{array}$ & $1865.59 \pm 122.34$ & $672 \pm 361$ & $288 \pm 155$ & $259 \pm 22$ & $4339 \pm 502$ & $\begin{array}{r}-0.0031 \pm 0.00036 \\
-0.0034 \pm 0.00038\end{array}$ & $430 \pm 41$ \\
\hline YYIII-1 & Equid & $\begin{array}{l}\text { enamel } \\
\text { dentine }\end{array}$ & $1989.56 \pm 278.50$ & $682 \pm 742$ & $317 \pm 345$ & $105 \pm 6$ & $4224 \pm 876$ & $\begin{array}{l}-0.0026 \pm 0.00052 \\
-0.0029 \pm 0.00053\end{array}$ & $471 \pm 72$ \\
\hline YYIII-2 & Cervid & $\begin{array}{l}\text { enamel } \\
\text { dentine }\end{array}$ & $1471.49 \pm 99.68$ & $437 \pm 321$ & $284 \pm 209$ & $115 \pm 6$ & $3956 \pm 494$ & $\begin{array}{l}-0.0036 \pm 0.00048 \\
-0.0041 \pm 0.00051\end{array}$ & $372 \pm 39$ \\
\hline YYIII-3 & Cervid & $\begin{array}{l}\text { enamel } \\
\text { dentine }\end{array}$ & $1665.20 \pm 216.00$ & $633 \pm 700$ & $188 \pm 208$ & $120 \pm 7$ & $4061 \pm 794$ & $\begin{array}{l}-0.0030 \pm 0.00059 \\
-0.0036 \pm 0.00063\end{array}$ & $410 \pm 60$ \\
\hline YYIII-4 & Cervid & $\begin{array}{l}\text { enamel } \\
\text { dentine }\end{array}$ & $1650.33 \pm 241.99$ & $942 \pm 880$ & $340 \pm 318$ & $144 \pm 14$ & $4546 \pm 986$ & $\begin{array}{l}-0.0038 \pm 0.00076 \\
-0.0041 \pm 0.00078\end{array}$ & $363 \pm 58$ \\
\hline YYIII-5a & Cervid & $\begin{array}{l}\text { enamel } \\
\text { dentine }\end{array}$ & $1846.79 \pm 89.74$ & $857 \pm 268$ & $502 \pm 157$ & $126 \pm 12$ & $4605 \pm 440$ & $\begin{array}{l}-0.0034 \pm 0.00034 \\
-0.0036 \pm 0.00035\end{array}$ & $401 \pm 33$ \\
\hline YYIII-5b & Cervid & $\begin{array}{l}\text { enamel } \\
\text { dentine }\end{array}$ & $2068.98 \pm 227.34$ & $946 \pm 641$ & $497 \pm 336$ & $129 \pm 12$ & $4692 \pm 788$ & $\begin{array}{l}-0.0029 \pm 0.00047 \\
-0.0033 \pm 0.00049\end{array}$ & $441 \pm 56$ \\
\hline
\end{tabular}




\section{Note:}

* Paleodoses of fossil samples were determined by single saturation exponential plus linear (EPL) fitting function.

** In situ dose rates' mean value of $3.12 \pm 0.58 \mathrm{~Gy} / \mathrm{ka}$ was taken for external gamma dose rate.

*** The AU-ESR ages of the samples were calculated using a program based on MATLAB software (Shao et al., 2012) with the following parameters and assumptions: alpha efficiency of $0.13 \pm 0.02$ (Grün and Katzenberger-Apel, 1994); dose rate conversion factors of Adamiec and Aitken (1998); Monte-Carlo beta attenuation factors (Marsh et al., 2002) based on the thickness of the enamel layer, before and after its preparation; water contents of 3 $\mathrm{wt} \%$ in the enamel, $7 \mathrm{wt} \%$ in the dentine and $15 \mathrm{wt} \%$ in sediment were assumed. 